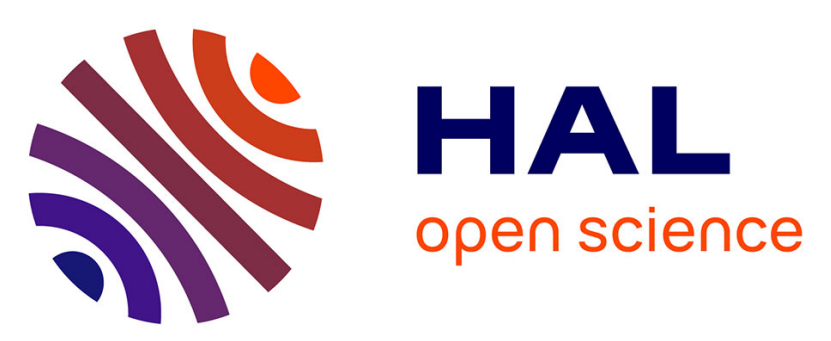

\title{
Games on the seashore of Salalah: the discovery of mancala games in Dhofar, Sultanate of Oman
}

Vincent Charpentier, Alex de Voogt, Rémy Crassard, Jean-françois Berger, Federico Borgi, Ali Al-Mashani

\section{- To cite this version:}

Vincent Charpentier, Alex de Voogt, Rémy Crassard, Jean-françois Berger, Federico Borgi, et al.. Games on the seashore of Salalah: the discovery of mancala games in Dhofar, Sultanate of Oman. Arabian Archaeology and Epigraphy, 2014, 25 (1), pp.115-120. 10.1111/aae.12040 . hal-01828888

\section{HAL Id: hal-01828888 https://hal.science/hal-01828888}

Submitted on 4 Jul 2018

HAL is a multi-disciplinary open access archive for the deposit and dissemination of scientific research documents, whether they are published or not. The documents may come from teaching and research institutions in France or abroad, or from public or private research centers.
L'archive ouverte pluridisciplinaire $\mathbf{H A L}$, est destinée au dépôt et à la diffusion de documents scientifiques de niveau recherche, publiés ou non, émanant des établissements d'enseignement et de recherche français ou étrangers, des laboratoires publics ou privés. 
ARABIAN

ARCHAEOLOGY

AND EPIGRAPHY

EDITOR-IN-CHIEF 10 DANIEL T. POT TS ASSOCIATE EDITOR I PETER STEIN

\section{\begin{tabular}{l|l|l|l|l|l|l|} 
VOL & N A Y 2014
\end{tabular}}

$x^{2}+y^{2}$ 


\section{Games on the seashore of Salalah: the discovery of mancala games in Dhofar, Sultanate of Oman}

During the 2013 fieldwork of the French archaeological mission along the shores of the Arabian Sea, mancala games were discovered on the seashore of Salalah at the site of Ad-Dahariz. They are cup-hole carvings made directly into rock slabs and distributed in six distinct zones of the site. They usually consist of fourteen cup-holes aligned in two lines of seven, two supplementary holes being sometimes present on each side. They are the first of their kind in South Arabia and can be compared to similar configurations of carved games elsewhere in Arabia, such as at Jebel al-Jassasiya, Qatar. This paper presents the potential origins of this game in the region, as well as a plausible dating of their use.

Keywords: mancala, hawalis, Ottomans, Dhofar, Oman

\section{Introduction}

The study of board games has accelerated since Murray's (1952) seminal publication with overviews that include an increasing number of so-called graffiti games (Bell 1979; Parlett 1999; Finkel 2007). Within the broad category of graffiti games, the commonest is probably those carved in stone that include games found on living rock surfaces and those cut into buildings and other man-made structures. Examples have been observed in excavations related to Roman and Greek antiquity by Austin $(1934,1935)$ and later by Bell (1979) and Bell and Roueché (2007), and in particular Schädler (1994, 1995, 1998). The latter made the important distinction between games from antiquity

\author{
Vincent Charpentier ${ }^{1}$ \\ Alex de $\operatorname{Voogt}^{2}$, Rémy \\ Crassard $^{3}$, Jean-François \\ Berger $^{4}$, Federico Borgi ${ }^{5}$, Ali \\ Al-Mashani ${ }^{6}$ \\ ${ }^{1}$ Inrap/CNRS, UMR 7041 \\ 'ArScAn', Maison Archéologie \\ \& Ethnologie, Nanterre, France \\ ${ }^{2}$ American Museum of Natural \\ History, New York City, USA \\ ${ }^{3}$ CNRS, UMR 5133 \\ 'Archéorient', Maison de l'Orient \\ et de la Méditerranée, Lyon, \\ France \\ ${ }^{4}$ CNRS, UMR 5600 'EVS-IRG', \\ Université de Lyon, Lyon, France \\ ${ }^{5}$ Université Paris 1 Panthéon- \\ Sorbonne, Paris, France \\ ${ }^{6}$ Ministry of Heritage and \\ Culture, Salalah, Sultanate of \\ Oman \\ e-mails: vincent.charpentier@inrap.fr; \\ adevoogt@amnh.org; remy.crassard@ \\ mom.fr
}




\section{CHARPENTIER ET AL.}

eral graffiti games more accurately. This is particularly true for cup-shaped holes that outside classical Roman and Greek sites can now be associated with known mancala, siga and tab games found mainly in the Middle East. Mancala games commonly consist of two rows of holes or depressions, siga games usually consist of a grid of $5 \times 5$ squares or holes, while tab games mostly consist of four rows of small holes or depressions. Each of these games has variations that could confuse the distinction between these games; for example, tab games resemble four-row mancala games. Unfortunately, the time period in which siga and tab games were developed and spread throughout the region is still little understood. Mancala games have so far been associated with the Ottoman Empire, which helps to understand their distribution and history. Mulvin and Sidebotham (2004) claim to have found mancala games associated with a Roman fort at Abu Sha'ar in Egypt. Schädler (1998), however, has shown that two rows of five holes can also be associated with the game of five lines, a game not associated with mancala. De Voogt (2010) found that the excavated Roman parts of Palmyra only showed two rows of five, while the parts that were later occupied by Ottoman or Arab garrisons featured different configurations.

In January 2013, the French archaeological mission located a group of regular horizontal cup-shaped engravings on the seashore of the city of Salalah, capital of Dhofar (Sultanate of Oman). The configurations point to graffiti games that are not only found in Oman but also on the Arabian Peninsula in general.

\section{A coastal lagoon: the khor of Ad-Dahariz or 'eastern khor'}

The French archaeological mission is developing a multidisciplinary approach, at the crossroads of archaeology and palaeogeography, in order to detect climatic and eustatic fluctuations that would have modified the equilibrium between natural environments and human groups (Berger et al. 2013; Charpentier et al. 2012, 2013). All along the $1000 \mathrm{~km}$ of the Omani side of the Arabian Sea, the mission is exploring favourable zones where different environments mix. Mangroves and lagoons are of particular interest, and a survey was carried out near the Khor Ad-Dahariz and Khor Sawli.

Ad-Dahariz is one of the principal lagoons of Dhofar and part of the plain of Salalah (with Rawri, Hassan, Sawli, Balid, Salalah, West and Thet). With a surface area of 150 ha, this narrow lagoon is fed by the monsoon rains that flow from Wādī Sahnut. Phragmites, Juncus and sedges develop on these mainly rocky shores, but Avicenna marina is not present. A rich zone for bird nesting, this khor has been designated a nature reserve (Al Muscati et al. 1995).

On either side of the khor, palaeo-forms corresponding to fossil coastal bands are clearly visible in the satellite images. We were able to locate the Terebralia palustris palaeo-mangrove, the disappearance of which was thought to be concomitant with that of the palaeo-mangroves of Al-Balid and Rawri and thus related to the same phenomena (lagoon closures, etc.; Hoorn \& Cremaschi 2004; Zarins 2007).

Between Rayzut and Taqah, the limestone banks on the coastal plain of Salalah have been much exploited. These outcropping banks can measure between 2 and $6 \mathrm{~m}$ in thickness and were much sought after (Costa 1979). Many quarries are still visible in the landscape. The site of AdDahariz was exploited for its limestone slabs, the removal of which has partially destroyed a settlement dating to the seventh-fifth millennia BC (Fig. 1). Surrounded by cotton fields and groves of coconut palms, the village of Ad-Dahariz dating to the nineteenth century AD was composed of 100 houses of stone and earth, occupied by fishermen and farmers. Protected by several watchtowers, in 1836 this village appears to have been the largest village in the area (Lorimer 1915; Miles 1919; Wharton 1900). The blocks extracted from the site were probably intended for the construction of the houses of this village, as well as, possibly, for the building or rebuilding of a part of the town of Al-Balid (AD 500-1700), 4 km away.

\section{The graffiti}

Some of the outcropping slabs present little cup-holes on their surface that are usually shallow and form short lines. Some much larger and deeper cup-holes are also attested. They have parallels on other Omani sites such as Khuwaymah KHU-2 and on the island of Masirah (unpublished), and also in the Jebel Jassasiyah in Qatar (e.g. Hassiba et al. 2012). The cup-hole carvings of Ad-Dahariz are distributed in six distinct zones, covering a large surface of the site. They usually consist of fourteen cup-holes aligned in two lines of seven (Fig. 2). These configurations are usually isolated, sometimes two sets together, and one large slab (no. 3) presents a whole group of them. The majority of the configurations identified consist of two lines of seven holes, two supplementary holes being sometimes present on each side. Partly buried under sand, slab no. 3 is composed of a whole assemblage of these (Fig. 3). 


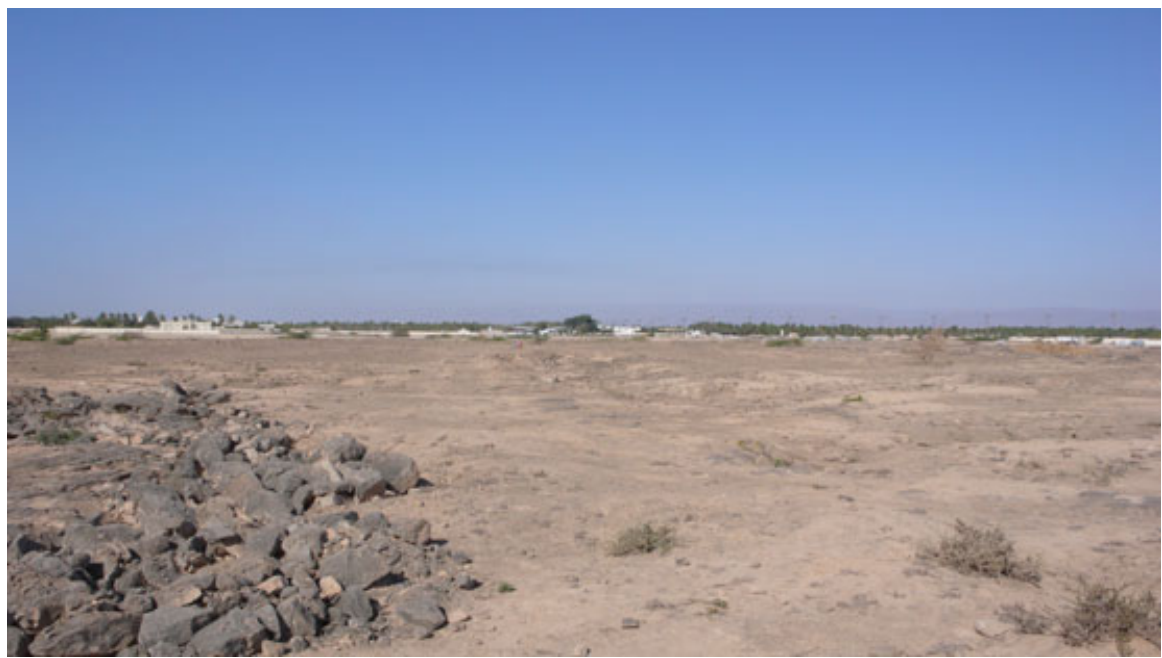

Fig. 1 .

A general view of the khor of Ad-Dahariz, Salalah.

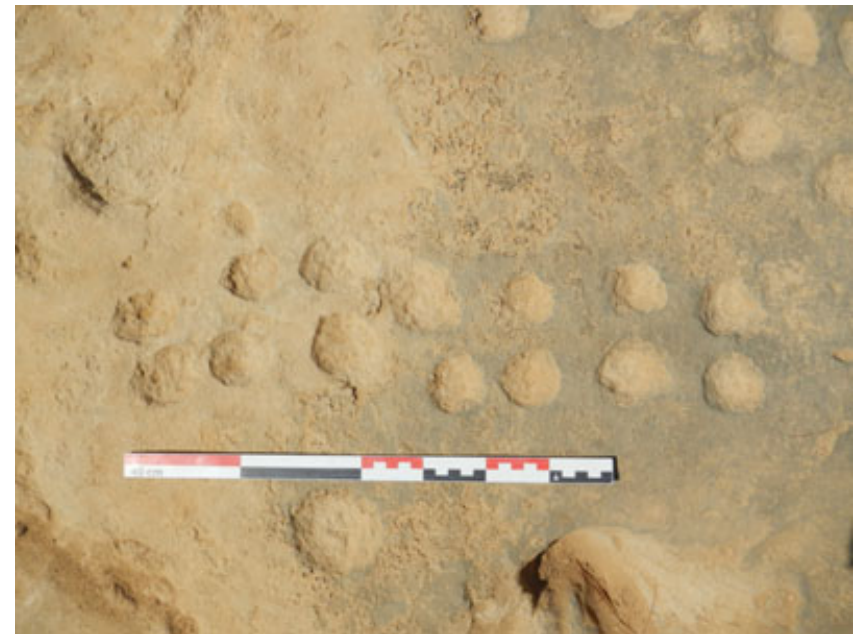

Fig. 2.

Rock carvings in the shape of a board game (detail), Salalah.

Besides the series of $7 \times 2$ elements, it also has in its centre a series of cup-holes that are more difficult to identify.

Several similar configurations of holes have been discovered in Arabia (Glob 1957). The most well known, identified by Peter Glob in the 1950s, is located on Jebel al-Jassasiya, a small limestone butte, which, like Ad-Dahariz, is by the sea, on the north-east coast of Qatar. Among the more than 900 listed petroglyphs, the most common (333 examples) are configurations of two lines of seven or nine cup-holes (Hassiba et al. 2012). Similar sets in the Wadi Rum and at Petra (Jordan) have been listed as well (Khrisat \& Akasheh 2002); in this area, however,

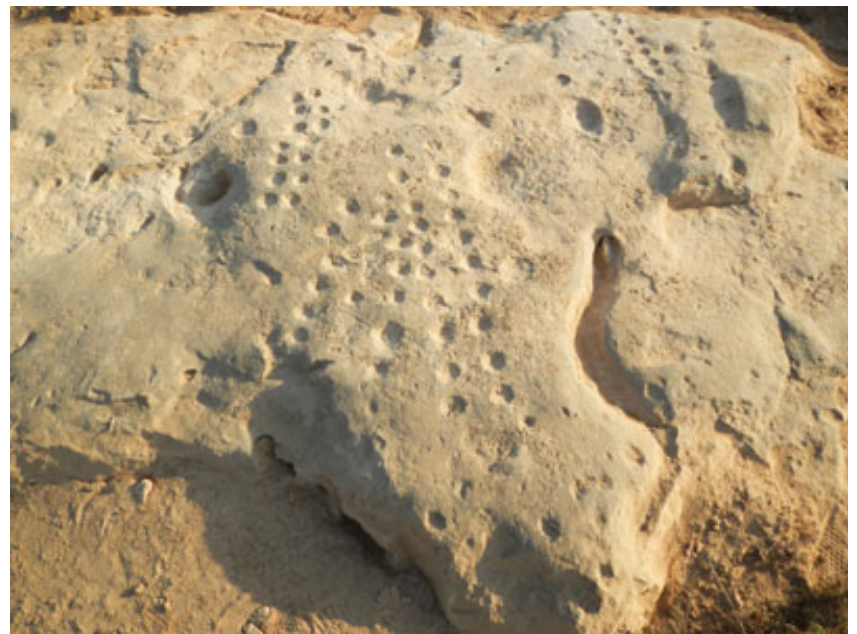

Fig. 3 .

Rock carvings in the shape of board games (slab no. 3), Salalah.

there are three or four rows of holes that commonly refer to tab games (Depaulis 2001) and should not be confused with mancala.

Two rows of holes are not necessarily instances of games, as holes may be used for grinding or other activities that could be associated with quarries or tool production. The possibility of a game is more likely when it is attested in a games context, that is, an area in which other games are present. Such a game context is not always available but, for instance, there is a game that can be identified as a game of tab attested in Qatar in a similar environment as those found in Oman. Next to a games 


\section{CHARPENTIER ET AL.}

context, the presence of a tradition of carving games in stone helps to identify not only the games but also the players. Two rows of seven holes are a common configuration for mancala games associated with the Ottomans in the Balkans (Bikić \& Vuković 2010), Syria (de Voogt 2010) and as far south as Sudan (de Voogt 2012). The region of Salalah falls comfortably within the zone of the former Ottoman Empire and makes the presence of mancala games in stone a likely proposition.

\section{The players}

In August 1507, the flotilla of Alfonso of Albuquerque left Socotra to ravage the maritime cities of Oman. In 1517 the Ottomans seized the coastal plains of Yemen, and particularly those of Aden in 1538. This date marks the beginning of the modern period in Yemen. Achieved under the reign of Suleiman the Magnificent, the Turkish domination of the country was to remain precarious. In 1635 the Ottomans withdrew to Mocha, and a large part of the troops deserted; the imam then accorded the last Ottomans the right to leave the country. At the end of the Middle Ages, the Rasulid era and the fourteenth century were periods of intense construction activity in the large city of Dhofar, Al-Balid. The arrival of Portuguese, Turkish and Mamluk forces, bringing with them new naval and military technologies to the Arabian Sea, influenced in part the decline of the city. It is known, however, that after the collapse of Al-Balid (the ancient Zafar), a part of the city was dismantled and many architectural blocks were reused (Costa 1979). Thus, monolithic pillars of the medieval city were reused in the old grand mosque of Ad-Dahariz during a later period (1979: fig. 49b). This reuse suggests that demand for stone and construction materials was still high in the area of Ad-Dahariz, at one time the capital of the large Khathiri tribe. The Ad-Dahariz quarry could very well have been exploited for its high-quality limestone during this period. The quarrymen of the sixteenth-seventeenth centuries $\mathrm{AD}$ were thus potential players of mancala. In Syria and Sudan, soldiers were identified as the most likely players and while this cannot be ruled out for Salalah, without further evidence the case for the quarrymen is more convincing here.

Although the association with the former Ottoman Empire is most likely, it does not eliminate the suggestion that this tradition of game production and game playing has continued to this day. Omanis still play a mancala game that can be found in the city of Muscat (Fig. 4), but the current mancala game in Oman, known as hawalis,

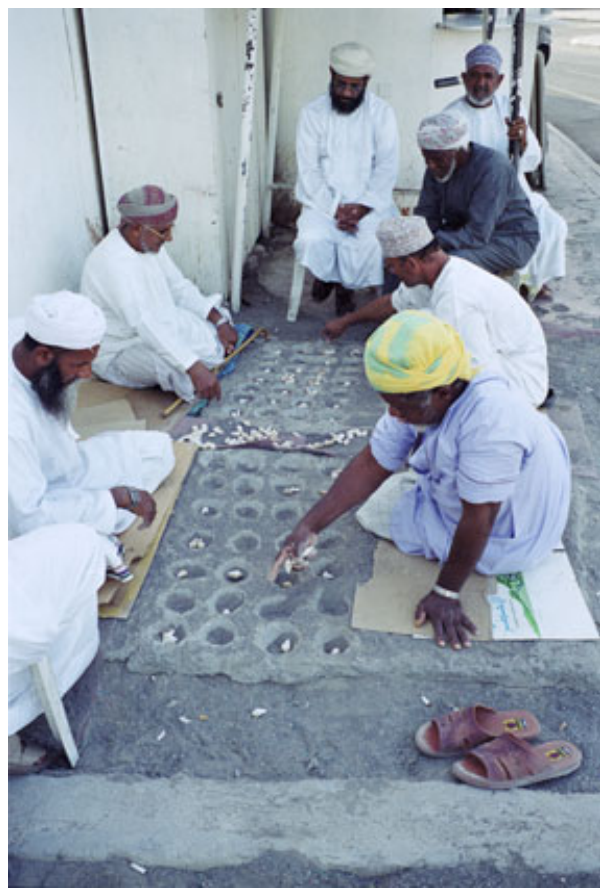

Fig. 4.

Omani men playing hawalis in Muscat, Oman (photograph Alex de Voogt, 2002).

has four rows of holes and is not related to the game played by the Ottomans. This game is associated with mancala as it is found in present-day Mozambique, where similar boards and playing rules have been observed and from where, most likely, the slave trade has aided the distribution of the game (de Voogt 2003). The fact that the two-row game is no longer played in Oman is an indication that the game departed with the Ottomans as it did, for instance, in Sudan (de Voogt 2012).

\section{Games in Arabia}

The recent dating of the games at Jebel Jassasiyah (Qatar), at the most 250 years old, fits with the conclusion that the Omani graffiti games were left during the Ottoman Empire. The configuration in Dhofar at Shisr has been associated with the Abbasid period (eighth-thirteenth centuries $\mathrm{AD}$ ) but has a board of fourteen cup-holes in three rows and is, therefore, more likely a tab game rather than a mancala game. Suggestions of an earlier presence of mancala in the Arab world are less likely in the absence of a game context or a tradition of such games for the given period. Games played in antiquity, such as the boards at Khor Rowri with five or six holes in two rows (J. Zarins, 
personal communication; Anonymous 2007) more likely refer to the game of five lines (Schädler 1998) rather than a mancala game for which there is little evidence in Arabian antiquity. As mentioned earlier, a possible playing practice that included wooden boards or sand precludes any definite statement that mancala was absent in antiquity.

The introduction of board games by way of caravan merchants to the great Nabataean cities is an attractive idea but remains to be proven. The arrival of the Ottomans seems to fit with the introduction of the game of mancala to the coasts of Arabia, an introduction, which, in Dhofar, is likely to have operated through Yemeni sailors travelling between ports. The game was then abandoned after the departure of the Ottomans. During the late nineteenth century, a period in which the Sultanate of Oman governed Zanzibar from Muscat, an African population arrived that introduced hawalis, the only mancala game known today in this region.

\section{Acknowledgements}

The French archaeological mission wishes to thank the archaeological authorities of the Sultanate of Oman, especially Dr Sultan Al-Bakri, director of the Department of Excavations and Archaeological Studies, and Prof. Maurizio Tosi, Ministry of Heritage and Culture. In France, the mission would like to thank the 'Consultative Commission for Excavations Abroad' of the Ministry of Foreign Affairs.

\section{References}

Anonymous. 2007. The Museum of the Frankincense Land. The history hall. Muscat: Office of the Advisor to His Majesty the Sultan for Cultural Affairs. [Unpublished.]

Austin, R.G. 1934. Roman board games. I. Greece \& Rome 4/10: 24-34.

Austin, R.G. 1935. Roman board games. II. Greece \& Rome 4/11: 76-82.

Bell, R.C. 1979. Board and table games from many civilizations. (2 volumes). Mineola, NY: Dover Publications.

Bell, R.C. \& Roueché, C.M. 2007. GraecoRoman pavement signs and game boards. Pages 106-109 in Finkel, I.L. (ed.), Ancient board games in perspective. London: British Museum Press.

Berger, J-F., Charpentier, V., Crassard, R., Martin, C. et al. 2013. The dynamics of mangrove ecosystems, changes in sea level and the strategies of Neolithic settlements along the coast of Oman (6000-3000 cal. BC). Journal of Archaeological Sciences 40/7: 3087-3104.

Bikić, V. \& Vuković, J. 2010. Board games reconsidered: mancala in the Balkans. Etnoantropoloki problemi 5/1: 183-209.

Charpentier, V., Berger, J-F., Crassard, R., Lacaze, M., Davtian, G. 2012. Prehistory and palaeo-geography of the coastal fringes of the Wahiba Sands and Bar alHikman, Sultanate of Oman, Sultanate of Oman. Proceedings of the Seminar for Arabian Studies 42: 57-78.
Charpentier, V., Berger, J-F., Crassard, R., Borgi, F. et al. 2013. Conquering new territories: when the first black boats sailed to Masirah Island. Proceedings of the Seminar for Arabian Studies 43: 85-98.

Costa, P.M. 1979. The study of the city of Zafar (al-Balid). Journal of Oman Studies 5: $111-150$.

de Voogt, A.J. 2003. Hawalis in Oman: a first account of expertise and dispersal of fourrow mancala in the Middle East. Board Games Studies 6: 95-98.

de Voogt, A.J. 2010. Mancala players at Palmyra. Antiquity 84/326: 1055-1066.

de Voogt, A.J. 2012. Mancala at the pyramids of Meroe. Antiquity 86/334: 1155-1166.

Depaulis, T. 2001. Jeux de parcours du monde arabo-musulman (Afrique du Nord et Proche-Orient). Journal of Board Game Studies 4: 53-76.

Finkel, I.L. (ed.). 2007. Ancient board games in perspective. London: British Museum Press.

Glob, P.V. 1957. Oltidsfund I Qatar (Prehistoric discoveries in Qatar). Kuml: 167-178.

Hassiba, R., Cieslinski, G.B., Chance, B., AlNaimi, F.A. et al. 2012. Determining the age of Qatari Jabal Jassasiyah Petroglyphs. QScience Connect 4: 1-16.

Hoorn, C. \& Cremaschi, M. 2004. Late Holocene paleoenvironmental history of coastal wetlands in Dhofar (Sultanate of Oman, Arabian Peninsula).
Palaeogeography, Palaeoclimatology, Palaeoecology 213: 1-3.

Khrisat, B. \& Akasheh, T. 2002. Gaming Boards from the Nabataean Capital City of Petra: documentation and study. (Abstracts of the Second Conference on Nabataean Studies, 29-31 October 2002, Petra, Jordan). Bulletin of Nabataean Studies.

Lorimer, J.G. 1915. Gazetteer of the Persian Gulf, Omān, and Central Arabia: Historical. (4 volumes). Calcutta: Superintendent Government Printing, India.

Miles, S.B. 1919. The Countries and Tribes of the Persian Gulf. Garnet \& Ithaca Press.

Mulvin, L. \& Sidebotham, S.E. 2004. Roman game boards from Abu Sha'ar (Red Sea coast, Egypt). Antiquity 78: 602-617.

Murray, H.J.R. 1952. A history of board games other than chess. Oxford: Oxford University Press.

Al Muscati, S., Daly, R., Gallagher, M., Eriksen, J. et al. 1995. The Sultanate of Oman. Pages 370-389 in Scott, D. (ed.), A Directory of Wetlands in the Middle East. Gland, Switzerland: IUCN/Slimbridge: IWRB.

Parlett, D. 1999. The Oxford history of board games. Oxford: Oxford University Press.

Schädler, U. 1994. Latrunculi-ein verlorenes strategisches Brettspiel der Römer. Homo Ludens: der spielende Mensch 4: 47-67. 


\section{CHARPENTIER ET AL.}

Schädler, U. 1995. XII Scripta, Alea, Tabula: new evidence for the Roman history of 'backgammon'. Pages 73-98 in de Voogt, A. (ed.), New Approaches to Board Games Research: Asian origins and future perspective. Leiden: International Institute for Asian Studies.
Schädler, U. 1998. Mancala in Roman Asia Minor. Board Games Studies 1: $10-25$.

Wharton, J. 1990. The red Sea and the Gulf Aden Pilot. London: Eyre \&

Spottiswoode/Great Britain Hydrographic Office, Great Britain Admiralty.
Zarins, J. 2007. Aspects of recent archaeological work at al-Balid (Zafar), Sultanate of Oman. Proceedings of the Seminar for Arabian Studies 37: 309-324. 


\section{ARABIAN}

\section{ARCHAEOLOGY}

\section{AND EPIGRAPHY}

VOL. $25 \quad$ NO. $1 \quad$ M A Y 2014

\section{Contents}

\section{Original Articles}

High-resolution geospatial surveying techniques provide new insights into rock-art landscapes at Shuwaymis, Saudi Arabia

The crowsteps motif in Nabataean architecture: insights into its meaning and use

The Nabataean 'Caesar' inscription from Khirbat az-Zūna

A new Nabataean inscribed bronze lamp

Dibba: an ancient port on the Gulf of Oman in the early Roman era

Building $\mathrm{G}$ at Makaynūn: a late pre-Islamic settlement above the ruins of a South Arabian town

'Nomad Villages' in north-eastern Jordan: from Roman Arabia to Umayyad Urdunn

New Kufic graffiti and inscriptions from Jordan

Games on the seashore of Salalah: the discovery of mancala games in Dhofar, Sultanate of Oman

Characteristics of Oman's archaeological resource: a preliminary review of management prospects

A note on the excavation of an Ottoman and British Mandate period Bedouin campground at Nahal

Be'erotayim West in the Negev desert, Israel

Erratum

1 R. Jennings, A. Parton, H.S. Groucutt, L. Clark-Balzan, P. Breeze, N.A. Drake, A. Alsharekh E M.D. Petraglia

22

37

43 